\title{
No recombination detected in artificial potyvirus mixed infections and between potyvirus derived transgenes and heterologous challenging potyviruses
}

\author{
Christof DIETRICH ${ }^{1}$, Jane MILLER ${ }^{2}$, Gaynor MCKENZIE ${ }^{2}$, László PALKOVICS ${ }^{3}$, Ervin BALÁZS ${ }^{4}$, Peter PALUKAITIS $^{2}$ \\ and Edgar MAISS ${ }^{5 *}$ \\ ${ }^{1}$ German Collection of Microorganisms and Cell Cultures, Plant Virus Division, Inhoffenstraße 7b, 38124 Braunschweig, Germany \\ 2 Scottish Crop Research Institute, Invergowrie, Dundee DD2 5DA, Scotland, UK \\ 3 Department of Plant Pathology, Corvinus University Budapest, 1118 Villányi ut 29, Hungary \\ 4 Department of Applied Genomics, Agricultural Research Institute, 2462 Martonvásár, Brunszvik u 2, Hungary \\ 5 Institute of Plant Diseases and Plant Protection, University of Hannover, Herrenhäuser Str. 2, 30419 Hannover, Germany
}

\begin{abstract}
Risk-assessment studies of virus-resistant transgenic plants (VRTPs) focussing on recombination of a plant virus with a transgenic sequence of a different virus should include a comparison of recombination frequencies between viruses in double-infected non-transgenic plants with those observed in singly infected transgenic plants to estimate recombination incidence in VRTPs. In this study, the occurrence of recombination events was investigated in non-transgenic plants double-infected with two different potyviruses, as well as in potyviral genomes in singly infected transgenic plants expressing potyvirus sequences. Different potyviruses, namely Potato virus A (PVA), Tobacco vein mottling virus (TVMV), two strains of Potato virus $Y$ (PVY-O, PVY-H) and two strains of Plum pox virus (PPV-NAT, PPV-SK68), were used in three combinations for double infection of a common host. Furthermore, transgenic plants expressing either potyviral coat protein (CP), helicase (Cl) or polymerase (NIb) coding sequences (PPV-NAT-CP, PVY-Cl, PVY-NIb) were singly-infected with a heterologous potyvirus, which was not targeted by the respective transgenic resistance. To identify recombinant potyviral sequences, a sensitive RT-PCR was developed to detect up to one recombinant molecule out of $10^{6}$ parental molecules. In 304 mixed infected non-transgenic plants, 92 mixed and 164 single infected transgenic plants screened for recombinant sequences no recombinant potyviral sequence was found. These results indicate that recombination events between different potyviruses in mixed infections and between a potyvirus infecting a potyvirus-resistant transgenic plant are likely to be very infrequent.
\end{abstract}

Keywords: potyvirus / transgenic plants / mixed infections / recombination / RT-PCR

\section{INTRODUCTION}

The use of virus-resistant transgenic plants (VRTPs) in agroecosystems is a considerably effective strategy to protect crops from severe diseases caused by plant viruses (Tepfer, 2002). Since VRTPs initially were reported (Powell-Abel et al., 1986) numerous plants have been developed that confer resistance to viruses (reviewed by Beachy, 1997; Tepfer, 2002). However, beside the benefits of VRTPs, it has been suggested that the release of transgenic plants into agro-ecosystems might engender ecological risks (reviewed by Tepfer, 2002). In the case of virus infections, two major types of potential risks arising from VRTPs have been considered. The first is

\footnotetext{
*Corresponding author: maiss@ipp.uni-hannover.de
}

recombination, while the second encompasses synergy, heterologous encapsidation and complementation. The second type consists of phenotypic effects that do not affect the viral genome. It also was shown that heterologous encapsidation and complementation can be suppressed by alterations in the transgene (Varrelmann and Maiss, 2000). In contrast, recombination leads to genomic modifications of viral genomes and has been assumed to be of greater impact, because mutant or recombinant genomes are heritable and may possibly result in the emergence of competitive viruses with altered biological properties (Aaziz and Tepfer, 1999a, Tepfer, 2002). For example, it was demonstrated by Wintermantel and Schoelz (1996) that viable and competitive recombinant Cauliflower mosaic virus could arise frequently from VRTPs under conditions of moderate or weak selection pressure. 


\section{Dietrich et al.}

Potyvirus is the largest genus of plant viruses (reviewed by López-Moya et al., 2000; Urcuqui-Inchima et al., 2001) with several species, such as Potato virus $Y$ (PVY), Plum pox virus (PPV) or Tobacco vein mottling virus (TVMV), causing severe agronomic losses. A series of VRTPs have been generated to control different potyviruses including the above-mentioned PVY (Lawson et al., 1990), TVMV (Moreno et al., 1998) and PPV (López-Moya et al., 2000), respectively. The possibility of RNA recombination in VRTPs has been demonstrated in general (Greene and Allison, 1994; Rubio et al., 1999) and has been confirmed for plants carrying a potyviral transgene (Varrelmann et al., 2000). However, the recombination events mentioned above were observed in experimental systems with high selection pressure, in which defective viral genomes were restored by recombination with the mRNA of a transgene of the same virus or a closely related virus strain leading to viable viruses. In contrast, several recombinants of natural origin have been detected from recombination events between strains of individual potyvirus species in non-transgenic plants, as reported for PPV (Cervera et al., 1993; Glasa et al., 2002; 2004), Lettuce mosaic virus (Krause-Sakate et al., 2004), Turnip mosaic virus (Tan et al., 2004) or PVY (Glais et al., 2002). Therefore, recombination is regarded to be an important process for generation of viral RNA variability leading to new potyviral strains. Recombination within potyviruses has been shown to occur by a template-switching model (Gal-On et al., 1998). Within potyviral populations recombination can be rather frequent (Revers et al., 1996) reaching up to $7 \%$ as shown for Watermelon mosaic virus (WMV; Moreno et al., 2004). Additionally, natural recombination crossover sites within the above mentioned viruses have been determined (Cervera et al., 1993; Glais et al., 2002; Glasa et al., 2004). Therefore, the presence of such recombination hot spots in transgenes could lead to an increased probability for recombination in VRTPs. However, at present there are no risk-assessment studies evaluating the occurrence and frequency of recombinational gene flow from potyviral transgenes to challenging potyviruses.

To establish whether incidence of recombination is higher in transgenic plants, a baseline reflecting the natural recombination situation is needed. Because recombination can occur in mixed infections between virus strains or between closely related viruses, it was suggested by Aaziz and Tepfer (1999a) that these events could be used as a baseline in risk-assessment studies for an estimation of the natural recombination incidence in double-infected plants. Using this baseline of recombination obtained under natural conditions, comparisons and calculations can be made with the occurrence and frequency of recombination events in VRTPs. Finally, this would allow an estimation of whether VRTPs contribute to an increased rate of recombination, or if recombination in these plants occurs in the range of the natural recombination frequency in a double-infected plant.

Based on the approach suggested by Aaziz and Tepfer (1999a), experiments were designed to investigate whether recombination occurs in potyviral mixed infections or in transgenic plants expressing potyviral sequences and infected with a heterologous potyvirus under experimental conditions. For this purpose, reversetranscription, polymerase chain reaction (RT-PCR) techniques were developed to screen non-transgenic plants for recombinants after double-infection with the virus pairs potato virus A (PVA)/O-strain of PVY (PVY-O), the non-aphid transmissible PPV (PPV-NAT)/TVMV or PPV-SK68/Hungarian strain of PVY (PVY-H), respectively. Subsequently, transgenic plants expressing potyviral sequences of PPV-NAT coat protein (CP) (PPV-NAT-CP), PVY helicase (CI) or PVY polymerase (NIb) (PVY-CI, PVY-NIb), respectively, were infected with either one or two potyviruses and also screened for the occurrence of recombinant sequences.

\section{RESULTS AND DISCUSSION}

\section{Identification of identical sequence clusters between potyvirus combinations}

The basic requirement for RNA recombination is the presence of very similar or identical parental templates in the same region of the corresponding genomes that enable template switching of the RNA-dependent RNApolymerase (Bujarski and Nagy, 1996). Because recombination was investigated in the virus combinations PPV-NAT/TVMV, PPV-SK68/PVY-H and PVY-O/PVA, genomic sequences were screened first for high sequence similarities to identify putative recombination sites. Clustal $\mathrm{X}$ sequence alignments of the potyviral cistrons revealed sequence identities between 33\% and $62 \%$ between sequence clusters (Tab. 1). In the case of PPV-NAT/TVMV, two perfect conserved regions with a length of $16 \mathrm{nt}$ and $18 \mathrm{nt}$, respectively, were found in the NIb and the CP. High similarities of $88 \%$ within two conserved sequence stretches of $43 \mathrm{nt}$ and $35 \mathrm{nt}$ were recognised in the $\mathrm{CI}$ and $\mathrm{NIb}$ cistrons, respectively, between PVY-O and PVA (Tab. 1). The comparison of PPV-SK68 and PVY-H showed two conserved regions in the genomic $3^{\prime}$-part (NIb, CP) consisting of 28 and $29 \mathrm{nt}$ stretches with similarities of $96 \%$ and $93 \%$, respectively. The observed similarities corresponded with the alignment data of Shukla and Ward (1988). Bujarski and Nagy (1996) showed for Brome mosaic virus that sequence similarities of at least $15 \mathrm{nt}$ between RNA2 and RNA3 were sufficient to promote efficient RNA2/RNA3 
No recombination in artificial potyvirus infections

Table 1. Levels of sequence identities between potyviral genomes and cistrons of different potyviruses.

\begin{tabular}{|c|c|c|c|c|c|c|c|c|c|}
\hline \multirow[t]{2}{*}{ Compared region } & \multicolumn{3}{|c|}{ Sequence identity [\%] } & \multicolumn{6}{|c|}{ Localisation of conserved regions ${ }^{\ddagger}[\mathrm{bp}]$} \\
\hline & $\begin{array}{c}\text { PPV-NAT/ } \\
\text { TVMV }\end{array}$ & $\begin{array}{c}\text { PPV-SK68/ } \\
\text { PVY-H }\end{array}$ & $\begin{array}{c}\text { PVY-O/ } \\
\text { PVA }\end{array}$ & & $\begin{array}{l}\text {-NAT/ } \\
\text { /MV }\end{array}$ & $\begin{array}{r}\mathrm{PP} \\
\mathrm{P}\end{array}$ & $\begin{array}{l}\text {-SK68/ } \\
\text { VY-H }\end{array}$ & & $\begin{array}{c}\text { PVY-O/ } \\
\text { PVA }\end{array}$ \\
\hline complete genome & 56 & 54 & 54 & & & & & & \\
\hline $\mathrm{P} 1 *$ & 48 & 44 & 42 & & & & & & \\
\hline HC-Pro & 56 & 47 & 46 & & & & & & \\
\hline $\mathrm{P} 3 * *$ & 51 & 42 & 44 & & & & & & \\
\hline $\mathrm{CI} * * *$ & 55 & 58 & 54 & & & & & $88 \%$ at & $\begin{array}{r}3806-3848 / \\
3774-3816\end{array}$ \\
\hline NIa & 52 & 56 & 57 & & & & & & \\
\hline $\mathrm{NIb}$ & 62 & 62 & 60 & $90 \%$ at & $\begin{array}{c}7572-7600 / \\
7429-7457\end{array}$ & $96 \%$ at & $\begin{array}{l}7908 / 7936 \\
7900 / 7928\end{array}$ & $88 \%$ at & $\begin{array}{l}7598-7632 / \\
7572-7606\end{array}$ \\
\hline $\mathrm{CP}$ & 54 & 52 & 60 & $100 \%$ at & $\begin{array}{c}9137-9154 / \\
8838-8855\end{array}$ & $93 \%$ at & $\begin{array}{l}9486 / 9515 \\
9292 / 9321\end{array}$ & & \\
\hline $3^{\prime}$-NTR & 46 & 34 & 33 & & & & & & \\
\hline
\end{tabular}

¥ Sequences from NCBI GenBank: D13751 (PPV-NAT), M92280 (PPV-SK68), X04083 (TVMV), Z21670 (PVA), M95491 (PVY-H) and U09509 (PVY-O). Only conserved regions of at least 16 nucleotides in length are considered.

recombination, while sequence identities of nine or fewer nucleotides reduced the level of detectable recombinants. Therefore, the length of sequence identities observed between the potyviruses was evaluated to be sufficient for generation of recombinant potyviral genomes.

Because natural recombination sites are mainly located in the 3'-end of PPV (Cervera et al., 1993; Glasa, 2002) and PVY (Boonham et al., 2002; Glais et al., 2002), the major search for recombinants focussed on the $3^{\prime}$-end of the potyviral genomes (Fig. 1). Additionally, due to the high similarity values between PVY and PVA, the central region (CI, see Figs. 1D and 1E) was screened for recombination.

\section{RT-PCR to identify potyviral recombinants}

Different RT-PCR procedures were developed depending on the respective virus combinations (see below). RNase $\mathrm{H}^{-}$reverse transcriptases were used to prevent possible in vitro recombination events during amplification that can be due to RNase $\mathrm{H}^{+}$activity (Fernandez-Delmond et al., 2004).

For the detection of recombinants, sets of primers specific for each of the viruses were developed (Tab. 2) and used in combinations given in Table 3 . The primers for PPV-NAT/TVMV spanned the $3^{\prime}$-region ( $3^{\prime}$-half of NIa, NIb, CP and parts of $3^{\prime}$-UTR, see Figs. 1B and 1C) of each virus, whereas one pair of primers amplified a fragment of about $1-1.5 \mathrm{~kb}$ from the parental templates. The primers were designed to have similar annealing temperatures to perform RT-PCR reactions under stan- dardized conditions as described in Materials and Methods.

To amplify recombinant potyviral sequences, a sense primer of virus A (e.g. P8+ from PPV-NAT) was used in conjunction with the antisense primer of virus B (e.g. T8 - from TVMV). Table 3 gives an overview of the primer pairs that were used. After optimization of the RT-PCR conditions (not shown) the sensitivity was evaluated for primers $\mathrm{T} 10+/ \mathrm{P} 10-$ (Fig. 2A) using artificial recombinant sequences. In vitro-generated transcripts of a PPV-NAT/TVMV chimeric sequence were successively diluted and used for RT-PCR with primers T10+/P10 - in the presence of RNA from a PPVNAT/TVMV double-infected plant. With this approach one recombinant molecule within $10^{6}$ parental molecules was detectable (not shown). The sensitivity tested with the primers A-CI1/Y-CI3 using a PVY/PVA chimeric sequence was shown to be $1: 10^{5}$, as was the sensitivity of detection of either PVA RNA or PVY RNA using the various homologous primer combinations (data not presented). In a similar approach for the detection of recombinant plant viruses from transgenic plants, Koenig and Büttner (2004) reported a detection limit of 1:10 . Due to the possibility of generating recombinational artefacts during the RT-PCR amplification (see above) the primer combinations (Tab. 3) were tested using a mixture of RNA extracted from two single-infected plants. As demonstrated in Figure 2B for the primer combinations T8+/P8-, P8+/T8-, T10+/P10- and P10+/T10-, no artificial recombinant sequences were detected. This also was the case for all other primer pairs tested with other virus combinations (not shown). Therefore, sensitive and 
A

\begin{tabular}{|l|c|c|c|c|c|c|c|c|}
\hline VPg & P1 & HC-Pro & P3 & Cl & Nla & NIb & CP & An \\
\hline $5^{\prime}$
\end{tabular}
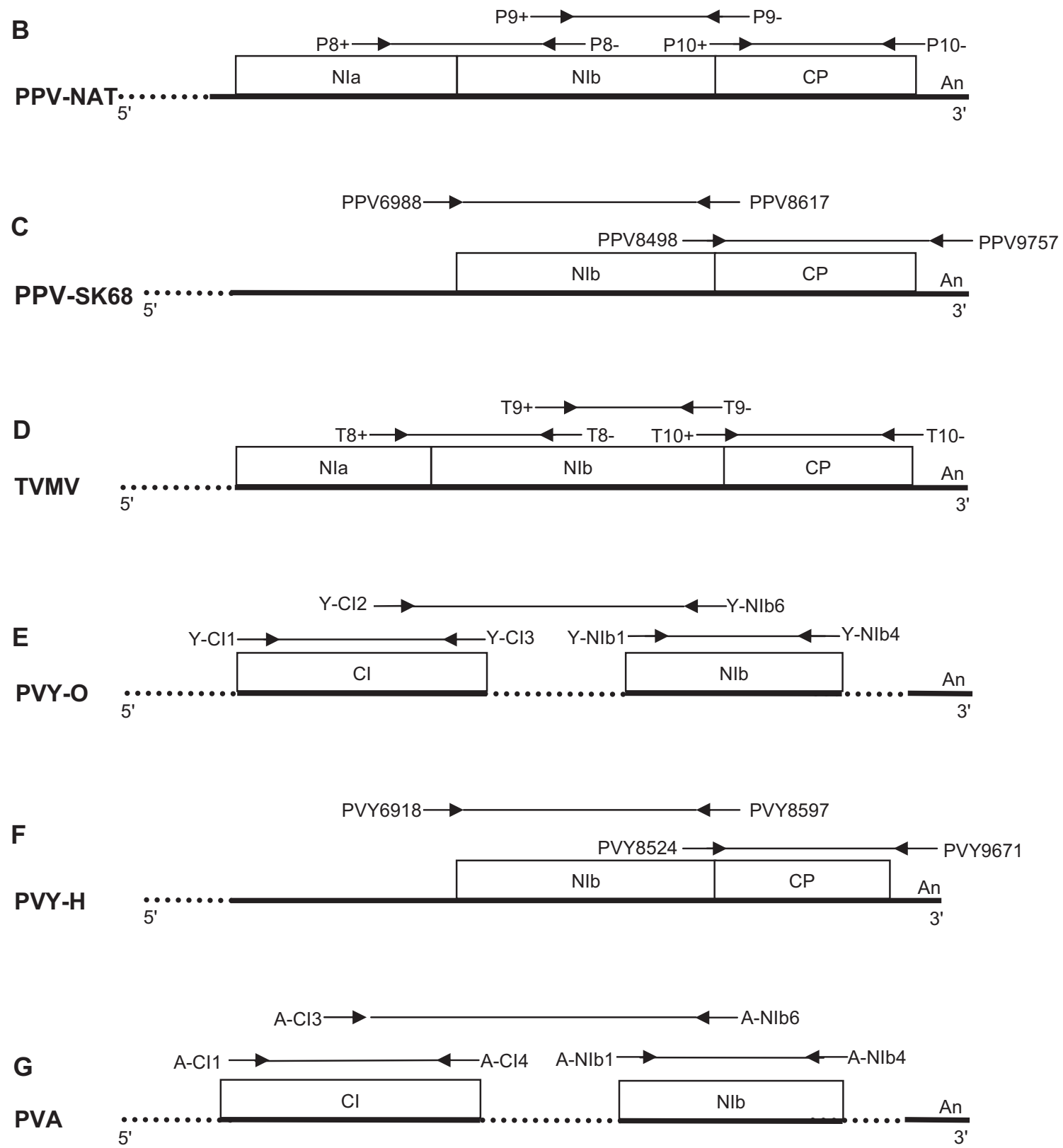

Figure 1. Localisation of primers on potyviral genomes for the detection of potyviral recombinants. A represents schematically the general genomic organisation of potyviruses. Drawings B-G indicate the localisation of primers (arrows) in central and 3'-genomic segments of PPV-NAT (B), PPV-SK68 (C), TVMV (D), PVY-O (E), PVY-H (F) and PVA (G), respectively. Abbreviations: VPg = viral protein, genome linked; P1, P3 = proteins 1 and 3; HC-Pro = helper component protease; $\mathrm{CI}=$ cylindrical inclusion body; NIa, $\mathrm{NIb}=$ nuclear inclusion bodies $\mathrm{a}$ and $\mathrm{b} ; \mathrm{CP}=$ coat protein; $\mathrm{An}=$ polyA. 
Table 2. Primers used in RT-PCR to detect potyviral recombinants.

\begin{tabular}{|c|c|c|c|}
\hline$\overline{\text { Primer }}$ & Target* & Location [bp] & Sequence $\left[5^{\prime}-3^{\prime}\right]$ \\
\hline$\overline{\mathrm{P} 8+}$ & PPV-NAT & $6746-6765$ & CGGATTACCCATCGTGAGCA \\
\hline P8- & PPV-NAT & 7776-7797 & TTTGACAGTTCCCTCTCACCGT \\
\hline $\mathrm{P} 9+$ & PPV-NAT & 7679-7698 & ATGGAGCGTTGGGATGACAA \\
\hline P9- & PPV-NAT & $8676-8695$ & TTCACGCCAGCAACAACTCA \\
\hline $\mathrm{P} 10+$ & PPV-NAT & $8557-8576$ & CCAACGTTGTTGTGCACCAA \\
\hline P10- & PPV-NAT & $9666-9685$ & TTGTCGAACACAGGCCCTTG \\
\hline PPV6988 & PPV-SK68 & $6988-7011$ & TGACGGACCTTGATAGGGAGTTCG \\
\hline PPV8617 & PPV-SK68 & $8617-8641$ & GCCGGTGCAGTTACCACAGTAGGTC \\
\hline PPV8498 & PPV-SK68 & $8498-8524$ & GACGGAAATTGAGAGATACCTCGAAGC \\
\hline PPV9757 & PPV-SK68 & $9757-9786$ & GTCTCTTGCACAAGAACTATAACCCGAATG \\
\hline $\mathrm{T} 8+$ & TVMV & $6884-6903$ & TGGAAGTCCGCTGGTTTCAA \\
\hline T8- & TVMV & $7887-7906$ & TGCGATGCTGATGGTTCACA \\
\hline T9+ & TVMV & $7643-7664$ & ACTAGGCGTCTGGAATGGATCA \\
\hline T9- & TVMV & $8543-8565$ & TTACAGAAGCCTTGCAGAACAGG \\
\hline $\mathrm{T} 10+$ & TVMV & $8332-8355$ & GGTTCATGTCTCACAGAGCACTCA \\
\hline $\mathrm{T} 10-$ & TVMV & $9393-9412$ & TTTTGTCTGGATGGCAGCGT \\
\hline Y-CI1 & PVY-O & $3656-3675$ & TCCTTAGACGATGTGATCAA \\
\hline $\mathrm{Y}-\mathrm{CI} 2$ & PVY-O & $4728-4747$ & GCTTCAAGAAAGGAGTAGCA \\
\hline $\mathrm{Y}-\mathrm{CI} 3$ & PVY-O & $5539-5558$ & CTTGGTGATGAACGAACTGC \\
\hline Y-NIb1 & PVY-O & $7010-7029$ & GCTAAGCACTCTGCGTGGAT \\
\hline Y-NIb4 & PVY-O & $8558-8577$ & GTGTCATTTGCTTGATGGTA \\
\hline Y-NIb6 & PVY-O & $7556-7575$ & AATGTCCTCGTCTTATTTGC \\
\hline PVY6918 & PVY-H & $6918-6944$ & GGGTCCATTGAAGCTCAAGGAGAGTAC \\
\hline PVY8597 & PVY-H & $8597-8625$ & CTCTTGTTTTGCATCCTTCTTAGTGCTTC \\
\hline PVY8524 & PVY-H & $8524-8548$ & GCCTTGGATGATGAACTTGAGTGCG \\
\hline PVY9671 & PVY-H & $9671-9703$ & GTCTCCTGATTGAAGTTTACAGTCACTGTTATG \\
\hline A-CI1 & PVA & $3586-3605$ & GCTTAATGAGTACCGTGGAA \\
\hline $\mathrm{A}-\mathrm{CI} 3$ & PVA & $4793-4812$ & CGTGTATGGACTTCCAATTT \\
\hline A-CI4 & PVA & $5506-5525$ & GAACTGCACTGCCTCTAAGT \\
\hline A-NIb1 & PVA & $6980-6999$ & CCAAGGATGTGATAGCAAGT \\
\hline A-NIb4 & PVA & $8514-8533$ & GCTTGGAAATACACCATGTC \\
\hline A-NIb6 & PVA & $7461-7480$ & ACACCTAATTGCCCAAAATA \\
\hline
\end{tabular}

and Z21670 (PVA).

reliable RT-PCR protocols for the detection of recombinant molecules in the presence of parental molecules were developed.

\section{Screening double-infected non-transgenic plants and single-infected transgenic plants for potyviral recombinants}

The occurrence of recombinant potyviruses was investigated in mixed infections of potyviruses and in potyvirus-infected transgenic plants expressing a potyviral sequence. The formation of recombinant potyviral sequences was scrutinized in three different potyvirus combinations (see above and Table 3), independently of whether infected non-transgenic or transgenic plants were examined. One hundred non-transgenic $N$. benthamiana plants double-infected with PPV-
NAT/TVMV, 55 non-transgenic $N$. benthamiana plants double-infected with PPV-SK68/PVY-H and 149 nontransgenic $N$. tabacum infected with PVY-O/PVA were screened for the occurrence of recombinant potyviral genomes with the primer combinations given in Table 3 . The positive controls showed the presence of the parental viruses in randomly selected samples (Fig. 2C and data not shown). Additionally, PVY-O/PVA infected transgenic $N$. tabacum plants carrying transgenes of PVY CI (41 plants) or PVY NIb (51 plants) were examined with 6 primer combinations (Tab. 3). Fifty plants of both PVY-transgenic lines were infected with PVA only, and 64 plants of the PPV-transgenic lines were infected with TVMV. The single-infected plants were examined with six (PVY-transgenic plants) and five primer combinations (PPV-transgenic plants), respectively. In the transgenic plants, the presence of the respective transgenic mRNA was verified by RT-PCR (Fig. 2C and data not 


\section{Dietrich et al.}

Table 3. Combinations of potyviruses used in mixed infections and potyviruses infecting potyvirus resistant transgenic plants.

\begin{tabular}{|c|c|c|}
\hline Potyviruses & Inoculated plants & Primer combinations \\
\hline \multicolumn{3}{|l|}{ Mixed infections } \\
\hline TVMV + PPV-NAT & $\begin{array}{l}100 \text { non-transgenic } \\
N . \text { benthamiana }\end{array}$ & $\begin{array}{l}\text { P8+/T8-, P8+/T9-, P9+/T9-, } \\
\text { P9+/T10-, P10+/T10-, T8+/P8-, } \\
\text { T8+/P9-, T9+/P9, T9+/P10-, } \\
\text { T10+/P9-, T10+/P9- }\end{array}$ \\
\hline PVY-H + PPV-SK68 & $\begin{array}{l}55 \text { non-transgenic } \\
N . \text { benthamiana }\end{array}$ & $\begin{array}{l}\text { PVY6918/PPV8498, } \\
\text { PPV6988/PVY8524, } \\
\text { PVY8597/PPV9757, } \\
\text { PPV8617/PVY9671 }\end{array}$ \\
\hline PVY-O + PVA & $\begin{array}{l}149 \text { non-transgenic } \\
\text { N. tabacum cv. 'Samsun' (NN) }\end{array}$ & $\begin{array}{l}\text { A-CI1/Y-CI3, Y-CI1/A-CI4, } \\
\text { A-NIb1/Y-NIb4, Y-NIb1/A-NIb4, } \\
\text { A-CI3/Y-NIb6, Y-CI2/A-NIb6 }\end{array}$ \\
\hline PVA + PVY-O & $\begin{array}{l}\text { 41 PVY-CI transgenic } \\
\text { N. tabacum 'Samsun' (NN) }\end{array}$ & $\begin{array}{l}\text { A-CI1/Y-CI3, Y-CI1/A-CI4, } \\
\text { A-NIb1/Y-NIb4, Y-NIb1/A-NIb4, } \\
\text { A-CI3/Y-NIb6, Y-CI2/A-NIb6 }\end{array}$ \\
\hline $\mathrm{PVA}+\mathrm{PVY}-\mathrm{O}$ & $\begin{array}{l}51 \text { PVY-NIb transgenic } \\
\text { N. tabacum 'Samsun' (NN) }\end{array}$ & $\begin{array}{l}\text { A-CI1/Y-CI3, Y-CI1/A-CI4, } \\
\text { A-NIb1/Y-NIb4, Y-NIb1/A-NIb4, } \\
\text { A-CI3/Y-NIb6, Y-CI2/A-NIb6 }\end{array}$ \\
\hline $\begin{array}{l}\text { Single infections } \\
\text { TVMV }\end{array}$ & $\begin{array}{l}64 \text { PPV-CP transgenic } \\
N . \text { benthamiana } 4.30 .45 \\
\text { and } 64 \text { PPV-CP transgenic } \\
\text { N. benthamiana } 17.27 .4\end{array}$ & $\begin{array}{l}\text { T9+/P9-, T9+P10-, } \mathbf{T 1 0 + / P 1 0 - ~} \\
\text { for line 4.30.45 } \\
\text { T9+/P9-, P10+/T10- for line } \\
\text { 17.27.4 }\end{array}$ \\
\hline PVA & $\begin{array}{l}50 \text { PVY-CI transgenic } \\
\text { N. tabacum 'Samsun' (NN) }\end{array}$ & $\begin{array}{l}\text { A-CI1/Y-CI3, Y-CI1/A-CI4, } \\
\text { A-NIb1/Y-NIb4, Y-NIb1/A-NIb4, } \\
\text { A-CI3/Y-NIb6, Y-CI2/A-NIb6 }\end{array}$ \\
\hline PVA & $\begin{array}{l}50 \text { PVY-NIb transgenic } \\
\text { N. tabacum 'Samsun' (NN) }\end{array}$ & $\begin{array}{l}\text { A-CI1/Y-CI3, Y-CI1/A-CI4, } \\
\text { A-NIb1/Y-NIb4, Y-NIb1/A-NIb4, } \\
\text { A-CI3/Y-NIb6, Y-CI2/A-NIb6 }\end{array}$ \\
\hline \multicolumn{3}{|c|}{ Parental viruses in single and mixed infections (in randomly selected samples) } \\
\hline $\begin{array}{l}\text { TVMV } \\
\text { PPV-NAT }\end{array}$ & & $\begin{array}{l}\mathrm{P} 8+/ \mathrm{P} 8-, \mathrm{P} 9+/ \mathrm{P} 9-, \mathrm{P} 10+/ \mathrm{P} 10- \\
\mathrm{T} 8+/ \mathrm{T} 8-, \mathrm{T} 9+/ \mathrm{T} 9-, \mathrm{T} 10+/ \mathrm{T} 10-\end{array}$ \\
\hline PVY-H & & $\begin{array}{l}\text { PVY6918/PVY8597, } \\
\text { PVY8524/PVY9671, }\end{array}$ \\
\hline PPV-SK68 & & $\begin{array}{l}\text { PPV8498/PPV9757, } \\
\text { PPV6988/PPV8617 }\end{array}$ \\
\hline PVA & & $\begin{array}{l}\text { A-CI1/A-CI4, A-NIb1/A-NIb4, } \\
\text { A-CI3/A-NIb6 }\end{array}$ \\
\hline PVY-O & & $\begin{array}{l}\text { Y-CI1/Y-CI3, Y-NIb1/Y-NIb4/ } \\
\text { Y-CI2/Y-NIb6 }\end{array}$ \\
\hline
\end{tabular}

Primer combinations that would amplify a recombinant resulting from a single switch are indicated by bold type.

shown). In all virus/virus combinations, as well as in the virus/transgenic plant approaches, no recombinant potyviruses were detected. Any RT-PCR products that were very rarely amplified with given primer combinations were shown by sequencing to results from non-specific amplification of one of the inoculated potyviruses (not shown).
The systems described above include VRTPs that expressed either low levels of the transgene (PVY NIb and PVY CI; unpublished data), or the transgene at levels sufficiently to detect accumulation of CP (PPV CP; Varrelmann and Maiss, 2000). The former depicts the situation most likely to be seen in the field, since most plants that will be used for resistance will be selected to show 

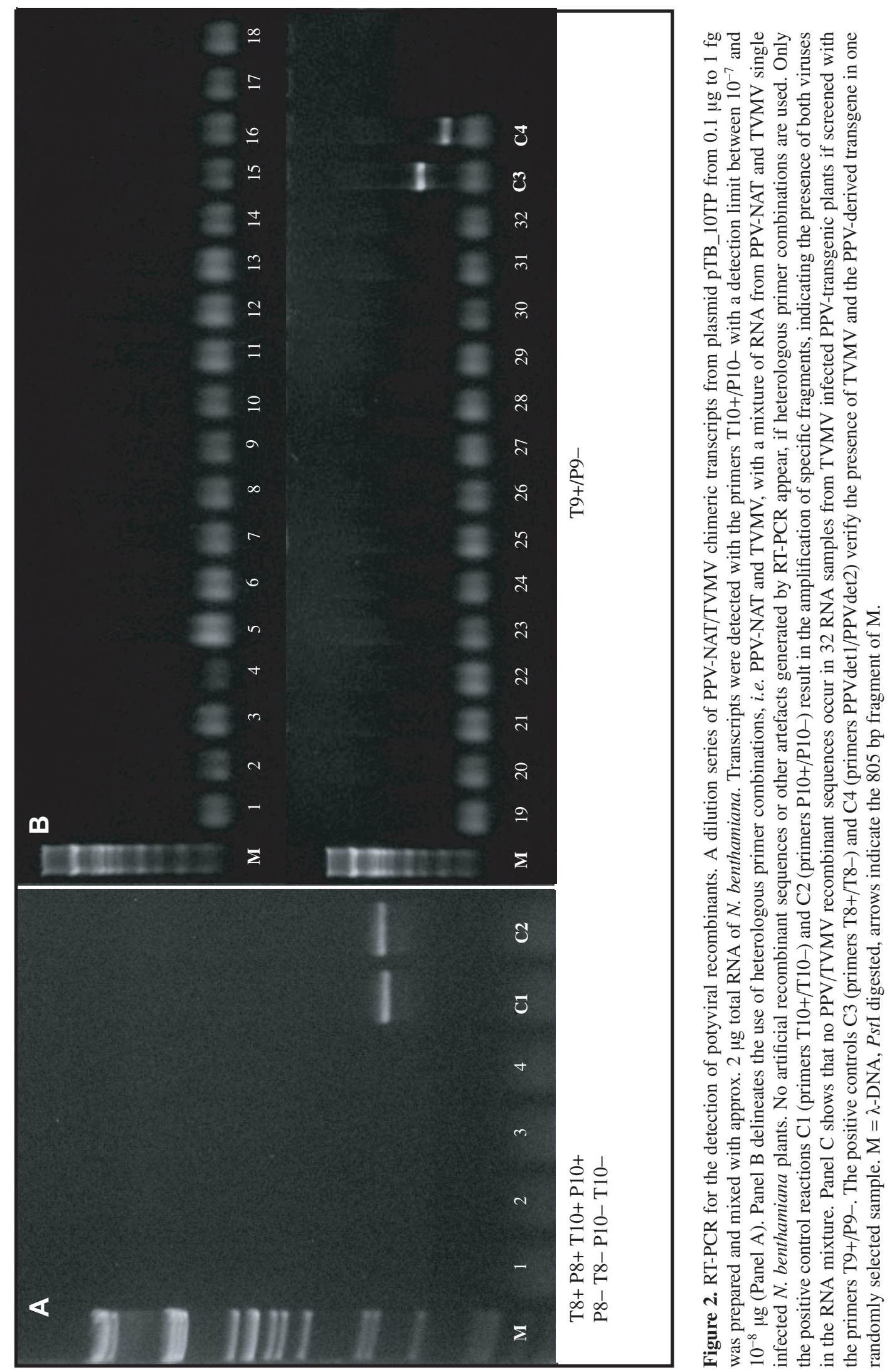


\section{Dietrich et al.}

resistance immediately to the homologous virus and this occurs predominantly by an RNA silencing mechanism (Beachy, 1997). By contrast, the latter example allowed us to explore recombination under conditions when the transgene expression level is high, such as situations when the RNA silencing of the transgene is suppressed by the expression of a RNA silencing suppressor protein of a heterologous virus (Savenkov and Valkonen, 2001). In the case of the PVY NIb and CI transgenic plants, the transgenes were not subject to RNA silencing suppression by infection with PVA (unpublished data).

In spite of sequence identities up to $60 \%$ and with perfect conserved regions of about $18 \mathrm{nt}$ in our virus/virus and virus/transgene combinations, this degree of sequence identity does not seem to be sufficient for effective and compatible recombination events between different potyviruses. Even if recombination is considered to be frequent within potyvirus populations (Bousalem et al., 2003; Moreno et al., 2004; Revers et al., 1996), our data indicate that recombination between different potyviruses is a rather uncommon event. A similar observation has been made by Meier and Truve (2006), who did not detect any recombinants in oat plants doubleinfected by two sobemoviruses (Cocksfoot mottle virus and Ryegrass mottle virus). This may arise from the absence of certain recombination enhancing sequence motifs neighboring identical regions in Brome mosaic virus that have been reported by Bujarski and Nagy (1996). In the case of potyviruses, in which the whole genome consists of one large open reading frame, only accurate inframe-exchanges can result in functional genomes. This may impose an additional limitation on recombinants involving potyviruses. But even if viable recombinants arise, it can be speculated that the resulting recombinant progeny is not necessarily competitive as shown by Fernandez-Delmond et al. (2004). These findings are in accordance with the conclusions of Gibbs (1994), that recombination among plant viruses occurs preferably between viruses of one group (intra-group, see above) and is less abundant between viruses of different groups (intergroup). Moreover, a high degree of sequence identity does not necessarily result in the formation of recombinant viruses as demonstrated by Koenig and Büttner (2004) for two strains of Beet necrotic yellow vein virus.

There are few data that report recombination events between different plant viruses, leading to viable and competitive viruses. This was shown for recombination between the cucumoviruses CMV and tomato aspermy virus (TAV) (Fernandez-Cuartero et al., 1994). Also, viable Sugarcane yellow leaf virus arose from a recombination event in a luteovirus/polerovirus combination (Moonan et al., 2000). In the absence of specific selection pressure, we cannot rule out that in the investigated potyvirus combinations tested recombination occurred below the detection limit or in genomic regions that were excluded from the screening. However, in the case of the mixed inoculum of PVA and PVY applied to PVY-resistant transgenic tobacco plants, no recombinants PVY with PVA CI or NIb sequences were detected, despite the strong selection pressure against PVY infection. This may indicate that the recombinant viruses, if formed, were not viable. This was similar to the situation with TAV/CMV recombinants obtained under low/no selection pressure (de Wispelaere et al., 2005). Aaziz and Tepfer (1999b) found three recombinant sequences in 83 doubleinfected plants. Thus, the number of plants examined in this work should have been sufficient to detect possible recombinant sequences. It was reported by Varrelmann et al. (2000), that recombination in the CP coding region only occurred if the complete $3^{\prime}$-UTR was present. In our experiments in $N$. benthamiana line 17.27.4, the $3^{\prime}$-end was partially deleted and therefore, recombination in this line was assumed to be less likely than in line 4.30.45. It should be mentioned that recombination resulting from a single switch between transgenic mRNA and viral RNA appears to be more likely than recombination events resulting from a double switch (Borja et al., 1999; Greene and Allison, 1994; 1996). While, in mixed infections in non-transgenic plants and in $N$. benthamiana line 4.30 .45 (with a complete $3^{\prime}$-UTR) the primer combinations used were able to detect recombinants resulting from a single switch, all other primer pairs given in Table 3 would have detected double recombinants, if they had occurred. Even if the likelihood of detecting single-switch recombinants was most likely in line 4.30 .45 (or in mixed infections), no recombinants were detected. However, in VRTPs recombinants are only of significance if they are competitive and display aberrant biological properties like enhanced symptom severity (Tepfer, 2002). Consequently, in terms of risk assessment of VRTPs, it can be concluded from our data, that recombination between sequences of different potyviruses, at least for the presented virus/virus and virus/transgene combinations, is negligible and does not promote a frequent emergence of recombinant progenies.

\section{Future risk assessment of VRTPs}

These results provide basic information for future risk assessment studies. For the identification of recombination hot spots it will be reasonable to investigate virus combinations that previously have been shown to be compatible for recombination, such as CMV/TAV (see above) or different strains of one virus. In the latter case it could be advantageous to perform experiments with different strains of PVY, since intra-specific recombination occurs between PVY strains (Glais et al., 2002). Because of the genome compatibility of PVY strains, the 
probability of finding recombinants of PVY/PVY is expected to be higher than detecting recombinants between PPV/TVMV, PPV-SK68/PVY-H or PVA/PVY-O. However, we can not state categorically that the time frame from inoculation to RNA isolation (up to four weeks) was sufficient to generate recombinant genomes, since Jridi et al. (2006) have recently shown that sequence heterogeneity in PPV occurred in a plum tree over 13 years after a single infection. In future studies, the experimental design should critically address the period from inoculation to detection of recombinant viruses.

Additionally, comparison of recombination frequencies of mixed infected non-transgenic plants with those of single infected VRTPs (Aaziz and Tepfer, 1999a) may not necessarily be appropriate. Dietrich and Maiss (2003) demonstrated spatial separation of viral populations in mixed infections, wherein only a few cells were double-infected. In contrast, in infected VRTPs, viral and transgene sequences are present in all infected cells. Therefore, a recombination frequency obtained from mixed infections is not necessarily comparable with one from virus infected VRTP, because the extent of the presence of the recombination partners (virus/virus or virus/transgene) is not the same in both systems. Nevertheless, the high frequency of recombinants detected between Watermelon mosaic virus isolates (Moreno et al., 2004) and the ready detection of recombinants involving other potyvirus strains indicate that the low number of double-infected cells is not a significant impediment to recombination among potyviruses.

\section{MATERIALS AND METHODS}

\section{Viruses and viral full-length clones}

The infectious full-length clone p35PPV-NAT of the non-aphid transmissible strain of PPV (Maiss et al., 1992) as well as wildtype virus isolates of TVMV (PV0253, DSMZ, Germany), PVA (SCRI collection), PVY-O (SCRI collection), PPV-SK68 (Palkovics et al., 1993) and PVY-H (Thole et al., 1993) were used in the respective experiments.

\section{Transgenic plants}

Two different transgenic homozygous $N$. benthamiana lines expressing PPV-CP were used (Varrelmann et al., 2000). Line 14.27.4. expresses the CP and the C-terminal 36 amino acid residues of the adjacent NIb protein of the aphid transmissible strain of PPV. It also contains a truncated $3^{\prime}$-NTR with $54 \mathrm{bp}$ present downstream of the $\mathrm{CP}$ gene. A second homozygous transgenic N. benthamiana line (4.30.45) was transformed with the PPVNAT-CP gene and the entire $3^{\prime}$-NTR. The PPV transgenic
$N$. benthamiana lines both contain single copies of the respective transgene and express the viral protein as shown by Varrelmann and Maiss (2000). The plants display a recovery resistance phenotype (Korte et al., 1995).

PVY-transgenic N. tabacum cv. 'Samsun' (NN) expressing sense and antisense of PVY-CI (Line 10-E, obtained from H. Barker, SCRI) or PVY-NIb (Line 10-7; Audy et al., 1994) were used to assess recombination between PVA and a PVY transgene. These lines both express only low levels of transgene (unpublished data).

\section{Inoculation of plants and sampling}

Infectious full-length cDNA of p35PPV-NAT was inoculated onto non-transgenic $N$. benthamiana plants by biolistic delivery as described previously (Dietrich and Maiss, 2002). PPV-NAT, TVMV, PPV-SK68 and PVY-H were maintained under standard greenhouse conditions in non-transgenic $N$. benthamiana plants. Transmission of virus was done by mechanical inoculation of plants with crude plant sap onto Celite-dusted leaves using approx. $0.5 \mathrm{~g}$ infected plant tissues ground in $2 \mathrm{~mL} 0.03 \mathrm{M}$ HEPES buffer ( $\mathrm{pH} 7)$. Mixed infections of non-transgenic plants with PPV-NAT and TVMV were carried out by using a mixture of equal amounts of plant sap obtained from plants singly infected with one of each virus. VRTPs were treated as described above with plant sap containing one virus.

PVY-O and PVA were maintained on N. tabacum cv. 'Samsun' (NN). Leaves of single-infected plants were extracted in water, and the extracts were rub inoculated onto Carborundum-dusted plants of either non-transgenic tobacco or N. tabacum cv. 'Samsun' (NN) transgenic Line 10-7 (NIb) or Line 10-E (CI). Extracts from singleinfected plants were mixed and used as inoculum to obtain double-infections by PVA and PVY-O.

Sampling and RNA extraction (see below) were carried out two to four weeks after inoculation.

\section{RT-PCR}

Different enzymes have been tested and used in RTPCR. In the PPV-NAT/TVMV and PPV-SK68/PVY-H approaches a one-step RT-PCR procedure with the SuperScript $^{\mathrm{TM}}$ One-Step RT-PCR Kit with Platinum ${ }^{\circledR}$ Taq (Invitrogen). In a $25 \mu \mathrm{L}$ reaction $0.3 \mu \mathrm{L}$ of the polymerase mixture was used with $0.5 \mu \mathrm{M}$ primers, $2 \mathrm{mM} \mathrm{MgSO}_{4}, 2 \mu \mathrm{L}$ RNA extract and the recommended $2 \mathrm{X}$ buffer. The reaction was carried out in a Thermocycler (T3, Biometra) at $45{ }^{\circ} \mathrm{C} / 30 \mathrm{~min}, 94{ }^{\circ} \mathrm{C} / 2 \mathrm{~min}$, $25 \times\left(94{ }^{\circ} \mathrm{C} / 15 \mathrm{~s}, 64{ }^{\circ} \mathrm{C} / 30 \mathrm{~s}, 72{ }^{\circ} \mathrm{C} / 90 \mathrm{~s}\right)$ and a final extension at $72{ }^{\circ} \mathrm{C}$ for $10 \mathrm{~min}$. Primers used for PPV-NAT/TVMV are listed in Table 2. The presence 


\section{Dietrich et al.}

of the PPV-transgenes in the transgenic $N$. benthamiana lines 17.27.4 and 4.30.45 was verified with the primers PPV-det1 (TCTCTGCCAAAGGTGAAGGGA) and PPV-det2 (GGTTCCGACGTTTCCATCCA).

For the combination PVY-O/PVA, the following RT-PCR conditions were used. $1 \mu \mathrm{g}$ RNA was incubated with $1 \mu \mathrm{L}$ primers $\left(5 \mathrm{pmol} \cdot \mu \mathrm{L}^{-1}\right)$ and water was added to a final volume of $9 \mu \mathrm{L}$. The mixture was incubated at $65^{\circ} \mathrm{C}$ for $5 \mathrm{~min}$ before cooling to room temperature. Reverse transcription was done at $37{ }^{\circ} \mathrm{C}$ for $1 \mathrm{~h}$ using 200 U MMLV-RT (RNase $\mathrm{H}^{-}$, Promega) with the recommended $10 \mathrm{X}$ reaction buffer, $2 \mu \mathrm{L} 25 \mathrm{mM} \mathrm{MgCl} 2$, $2 \mu \mathrm{L}$ BSA $(0.1 \%), 1 \mu \mathrm{L}$ DTT $(0.1 \mathrm{M}), 40 \mathrm{U}$ RNasIn and filled up to $20 \mu \mathrm{L}$ with water. PCR reactions were done with $0.2 \mu \mathrm{L}$ RT mix, $1 \mu \mathrm{L} 10$ X PCR buffer, $1.25 \mu \mathrm{L} 25 \mathrm{mM} \mathrm{MgCl} \mathrm{Mg}_{2}, 0.4 \mu \mathrm{L}$ dNTPs $(10 \mathrm{mM}), 1 \mu \mathrm{L}$ of each primer $\left(10 \mathrm{pmol} \cdot \mu \mathrm{L}^{-1}\right), 1 \mathrm{U}$ Taq-Polymerase (Boehringer) and water to $20 \mu \mathrm{L}$. The mixture was incubated at $94{ }^{\circ} \mathrm{C} / 5 \mathrm{~min}$, and then 30 cycles of $94^{\circ} \mathrm{C} / 30 \mathrm{~s}$, $55^{\circ} \mathrm{C} / 30 \mathrm{~s}, 72^{\circ} \mathrm{C} / 90 \mathrm{~s}$, and a final extension step at $72{ }^{\circ} \mathrm{C}$ for $10 \mathrm{~min}$.

\section{Plasmid construction and in vitro transcription}

Plasmids containing chimeric sequences of viruses have been constructed to serve as a positive control for the detection of recombinants and to determine the detection limit with the primers T10+/P10-in RT-PCR. A plasmid with a PPV-NAT/TVMV chimeric sequence was prepared by digesting a TVMV full-length clone (pXBS; Domier et al., 1986) with BamHI/EcoRI and cloning a 1748 bp fragment into pTrueBlue (Slilaty and Lebel, 1998) giving pTB_10T. After digestion of p35PPV-NAT (Maiss et al., 1992 ) with $E c o$ RI/SacI, a 836 bp fragment was fused to the TVMV sequence of pTB_10T (pTB_10TP).

RNA transcripts of pTB_10TB were obtained after linearizing the plasmid with $P v u \mathrm{II}$ and transcription (T7 Transcription Kit; Fermentas) according to the manufacturer's instructions.

The PVY-O/PVA CI chimeric plasmid pAY10 was generated for the determination of the detection limit of the primers A-CI1/Y-CI3. The insert consisted of PVA sequences (2914-4047) fused to PVY-O sequences (4192-5557) at the common BamHI site.

\section{RNA isolation methods}

For RNA isolation, primary and systemically infected leafs of transgenic or non-transgenic $N$. benthamiana and N. tabacum cv. 'Samsun' (NN) were taken. Total RNA of transgenic or non-transgenic plants infected with either PPV-NAT or TVMV or both have been prepared according to Menzel et al. (2002). RNAs from
PVA and/or PVY-O infected tobacco plants and doubleinfected PPV-SK68/PVY-H non-transgenic $N$. benthamiana plants were extracted using the RNAEasy plant RNA mini-extraction kit (QIAGEN), according to the manufacturer's instructions.

\section{ACKNOWLEDGEMENTS}

The authors would like to thank Dr. Tepfer and Dr. Artaud for coordinating and supporting the VRTP IMPACT project. This work was supported by contract no. QLK3CT-2000-00361 from the European Commission and was done as part of the VRTP IMPACT research consortium.

Received January 11, 2007; accepted April 27, 2007.

\section{REFERENCES}

Aaziz R, Tepfer M (1999a) Recombination in RNA viruses and in virus-resistent transgenic plants. J. Gen. Virol. 80: 13391346

Aaziz R, Tepfer M (1999b) Recombination between genomic RNAs of two cucumoviruses under conditions of minimal selection pressure. Virology 263: 282-289

Audy P, Palukaitis P, Slack SA, Zaitlin M (1994) Replicasemediated resistance to potato virus $\mathrm{Y}$ in transgenic tobacco plants. Mol. Plant-Microbe Interact. 7: 15-22

Beachy RN (1997) Mechanisms and applications of pathogen-derived resistance in transgenic plants. Curr. Opin. Biotechnol. 8: 215-220

Boonham N, Walsh K, Preston S, North J, Smith P, Barker I (2002) The detection of tuber necrotic isolates of Potato virus $Y$, and the accurate discrimination of $\mathrm{PVY}(\mathrm{O}), \mathrm{PVY}(\mathrm{N})$ and PVY $(\mathrm{C})$ strains using RT-PCR. J. Virol. Methods 102: $103-112$

Borja M, Rubio T, Scholthof HB, Jackson AO (1999) Restoration of wild-type virus by double recombination of tombusvirus mutants with a host transgene. Mol. PlantMicrobe Interact. 12: 153-162

Bousalem M, Dallot S, Fuji S, Natsuaki KT (2003) Origin, world-wide dispersion, bio-geographical diversification, radiation and recombination: an evolutionary history of Yam mild mosaic virus (YMMV). Infect. Genet. Evol. 3: 189-206

Bujarski JJ, Nagy PD (1996) Different mechanisms of homologous and nonhomologous recombination in Brome mosaic virus: role of RNA sequences and replicase proteins. Semin. Virol. 7: 363-372

Cervera MT, Riechmann JL, Martín MT, García JA (1993) 3'-Terminal sequence of Plum pox virus PS and o6 isolates: evidence for RNA recombination within the potyvirus group. J. Gen. Virol. 74: 329-334 
de Wispelaere M, Gaubert S, Trouilloud S, Belin C, Tepfer M (2005) A map of the diversity of RNA3 recombinants appearing in plants infected with cucumber mosaic virus and tomato asperny virus. Virology 331: 117-127

Dietrich C, Maiss E (2002) Red fluorescent protein DsRed from Discosoma sp. as a reporter protein in higher plants. Biotechniques 32: 286-293

Dietrich C, Maiss E (2003) Fluorescent labelling reveals spatial separation of potyvirus populations in mixed infected Nicotiana benthamiana plants. J. Gen. Virol. 84: 2871-2876

Domier LL, Franklin KM, Shahabuddin M, Hellmann GM, Overmeyer JH, Hiremath ST, Siaw MFE, Lomonossoff GP, Shaw JG, Rhoads RE (1986) The nucleotide sequence of Tobacco vein mottling virus RNA. Nucleic Acids Res. 14: 5417-5430

Fernandez-Cuartero B, Burgyan J, Aranda MA, Salanki K, Moriones E, Garcia-Arenal F (1994) Increase in the relative fitness of a plant virus RNA associated with its recombinant nature. Virology 203: 373-377

Fernandez-Delmond I, Pierrugues O, de Wispelaere M, Guilbaud L, Gaubert S, Diveki Z, Godon C, Tepfer M, Jacquemond M (2004) A novel strategy for creating recombinant infectious RNA virus genomes. J. Virol. Methods 121: 247-257

Gal-On A, Meiri E, Raccah B, Gaba V (1998) Recombination of engineered defective RNA species produces infective potyvirus in planta. J. Virol. 72: 5268-5270

Gibbs MJ (1994) Risks in using transgenic plants? Science 264: $1650-1651$

Glais L, Tribodet M, Kerlan C (2002) Genomic variability in Potato potyvirus $Y$ (PVY): evidence that $\mathrm{PVY}(\mathrm{N}) \mathrm{W}$ and PVY(NTN) variants are single to multiple recombinants between PVY $(\mathrm{O})$ and PVY(N) isolates. Arch. Virol. 147: 363378

Glasa M, Palkovics L, Kominek P, Labonne G, Pittnerova S, Kudela O, Candresse T, Subr Z (2004) Geographically and temporally distant natural recombinant isolates of Plum pox virus (PPV) are genetically very similar and form a unique PPV subgroup. J. Gen. Virol. 85: 2671-2681

Glasa M, Marie-Jeann V, Moury B, Kúdela O, Quiot J-B (2002) Molecular variability of the $\mathrm{P} 3-6 \mathrm{~K}_{1}$ region among geographically and biologically distinct isolates of Plum pox virus. Arch. Virol. 147: 563-575

Greene AE, Allison RF (1994) Recombination between viralRNA and transgenic plant transcripts. Science 263: 14231425

Greene AE, Allison RF (1996) Deletions in the 3' untranslated region of cowpea chlorotic mottle virus transgene reduce recovery of recombinant viruses in transgenic plants. Virology 225: 231-234

Jridi C, Martin JF, Marie-Jeanne V, Labonne G, Blanc S (2006) Distinct viral populations differentiate and evolve independently in a single perennial host plant. J. Virol. 80: 2349-2357
Koenig R, Büttner G (2004) Strategies for the detection of potential Beet necrotic yellow vein virus genome recombinations which might arise as a result of growing A type coat protein gene-expressing sugarbeets in soil containing B type virus. Transgenic Res. 13: 21-28

Korte AM, Maiss E, Kramer I, Casper R (1995) Biosafety considerations of different Plum pox potyvirus (PPV) genes used for transformation of plants. Acta Hort. 368: 280-284

Krause-Sakate R, Fakhfakh H, Peypelut M, Pavan MA, Zerbini FM, Marrakchi M, Candresse T, Le Gall O (2004) A naturally occurring recombinant isolate of Lettuce mosaic virus. Arch. Virol. 149: 191-197

Lawson C, Kaniewski W, Haley L, Rozman R, Newell C, Sanders P, Tumer NE (1990) Engineering resistance to mixed virus infection in a commercial potato cultivar: resistance to Potato virus $X$ and Potato virus $Y$ in transgenic Russet Burbank. Biotechnology 8: 127-134

López-Moya JJ, Fernández-Ferández MR, Cambra M, García JA (2000) Biotechnological aspects of Plum pox virus. J. Biotechnol. 76: 121-136

Maiss E, Timpe U, Brisske-Rode A, Lesemann D-E, Casper R (1992) Infectious in vivo transcripts of a Plum pox potyvirus full-length cDNA clone containing the Cauliflower mosaic virus 35S RNA promoter. J. Gen. Virol. 73: 709-713

Meier M, Truve E (2006) An attempt to identify recombinants between two sobemoviruses in doubly infected oat plants. Environ. Biosafety Res. 5: 47-56

Menzel W, Jelkmann W, Maiss E (2002) Detection of four apple viruses by multiplex RT-PCR assays with coamplification of plant mRNA as internal control. J. Virol. Meth. 99: 81-92

Moonan F, Molina J, Mirkov TE (2000) Sugarcane yellow leaf virus: an emerging virus that has evolved by recombination between luteoviral and poleroviral ancestors. Virology 269: $156-171$

Moreno IM, Malpica JM, Diaz-Pendon JA, Moriones E, Fraile A, García-Arenal F (2004) Variability and genetic structure of the population of Watermelon mosaic virus infecting melon in Spain. Virology 318: 451-60

Moreno M, Bernal JJ, Jimenez I, Rodriguez-Cerezo E (1998) Resistance in plants transformed with the P1 or P3 gene of Tobacco vein mottling potyvirus. J. Gen. Virol. 79: 2819-2827

Palkovics L, Burgyan J, Balázs E (1993) Comparative sequence analysis of four complete primary structures of Plum pox virus strains. Virus Genes 7: 339-347

Powell-Abel P, Nelson RS, De B, Hoffmann N, Rogers SG, Fraley RT, Beachy RN (1986) Delay of disease development in transgenic plants that express the Tobacco mosaic virus coat protein gene. Science 232: 738-763

Revers F, Le Gall O, Candresse T, Le Romancer M, Dunez J (1996) Frequent occurrence of recombinant potyvirus isolates. J. Gen. Virol. 77: 1953-1965

Rubio T, Borja M, Scholthoff HB, Jackson AO (1999) Recombination with host transgenes and effect on virus 


\section{Dietrich et al.}

evolution: an overview and opinion. Mol. Plant-Microbe Interact. 12: 87-92

Savenkov EI, Valkonen JPT (2001) Coat protein genemediated resistance to Potato virus A in transgenic plants is suppressed following infection with another potyvirus. $J$. Gen. Virol. 82: 2275-2278

Shukla DD, Ward CW (1988) Amino acid sequence homology of coat protein as a basis for identification and classification of the potyvirus group. J. Gen. Virol. 69: 2703-2710

Slilaty SN, Lebel S (1998) Accurate insertional inactivation of lacZ $\alpha$ : construction of pTrueBlue and M13TrueBlue cloning vectors. Gene 213: 83-91

Tan Z, Wada Y, Chen J, Ohshima K (2004) Inter- and intralineage recombinants are common in natural populations of Turnip mosaic virus. J. Gen. Virol. 85: 2683-2696

Tepfer M (2002) Risk assessment of virus-resistant transgenic plants. Annu. Rev. Phytopathol. 40: 467-491
Thole V, Dalmay T, Burgyan J, Balázs E (1993) Cloning and sequencing of potato virus $\mathrm{Y}$ (Hungarian isolate) genomic RNA. Gene 123: 149-156

Urcuqui-Inchima S, Haenni AL, Bernardi F (2001) Potyvirus proteins: a wealth of functions. Virus Res. 74: $157-175$

Varrelmann M, Maiss E (2000) Mutations in the coat protein gene of Plum pox virus suppress particle assembly, heterologous encapsidation and complementation in plants of Nicotiana benthamiana. J. Gen. Virol. 81: 567-576

Varrelmann M, Palkovics L, Maiss E (2000) Transgenic or plant expression vector-mediated recombination of Plum pox virus. J. Virol. 74: 7462-7469

Wintermantel WM, Schoelz JE (1996) Isolation of recombinant viruses between Cauliflower mosaic virus and a viral gene in transgenic plants under conditions of moderate selection pressure. Virology 223: 156-164 